\title{
KEGIATAN MENULIS PADA EKSTRAKURIKULER JURNALISTIK DI SMA NEGERI 1 MENGWI
}

\author{
Ni Putu Ana Yuspidayanti ${ }^{1}$, I Wayan Artika², I Gede Nurjaya ${ }^{3}$ \\ Jurusan Pendidikan Bahasa dan Sastra Indonesia \\ Universitas Pendidikan Ganesha \\ Singaraja, Indonesia \\ e-mail: \{ana.yuspida@gmail.com, wayan.artika@undiksha.ac.id, \\ gedenuriaya@gmail.com\}
}

\begin{abstract}
ABSTRAK
Penelitian ini bertujuan mengkaji (1) perencanaan, (2) pelaksanaan, dan (3) hambatan yang dihadapi siswa dalam kegiatan menulis pada ekstrakurikuler jurnalistik di SMA Negeri 1 Mengwi. Penelitian ini menggunakan rancangan deskriptif kualitatif. Subjek penelitian ini adalah siswa kelas XI IBB dan pembina ekstrakurikuler jurnalistik di SMA Negeri 1 Mengwi. Objek penelitian ini adalah pelaksanaan kegiatan menulis pada ekstrakurikuler jurnalistik. Data dikumpulkan menggunakan metode wawancara, metode observasi, metode kuisioner, dan dokumentasi. Data dianalisis menggunakan teknik deskriptif kualitatif. Hasil penelitian menunjukkan (1) Perencanaan kegiatan menulis pada ekstrakurikuler jurnalistik disusun dalam bentuk program kerja. Program kerja dirancang menjadi dua, yaitu program kerja semester ganjil dan program kerja semester genap. Komponen yang terdapat dalam program kerja tersebut meliputi tujuan, sasaran, uraian kegiatan, nilai karakter, dan indikator karakter. (2) Pelaksanaan kegiatan menulis pada ekstrakurikuler jurnalistik meliputi kegiatan menulis berita, tajuk rencana, opini, laporan utama, laporan khusus, resensi, dan penulisan sastra. Pembina menggunakan metode ceramah, tanya jawab, diskusi, praktik, serta menggunakan koran sebagai media untuk memudahkan siswa dalam menulis. Selain itu, pembina selalu mengajak siswa untuk peka terhadap isu-isu yang sedang ramai untuk diperbincangkan. Siswa mampu menghasilkan tulisan-tulisan jurnalistik, dan tulisan tersebut dikoreksi pada akhir pelatihan kegiatan menulis. (3) Hambatan yang dihadapi siswa dalam kegiatan menulis meliputi hambatan umum dan khusus. Selain hambatan yang dihadapi siswa, pembina juga mengalami hambatan ketika menulis yaitu keterbatasan pengetahuan terkait jurnalistik.
\end{abstract}

Kata kunci : ekstrakurikuler, jurnalistik, menulis

\section{ABSTRACT}

This study aimed for investigating: (1) planning, (2) applying, and (3) problem faced by students during journalistic writing as extra-curricular activities in SMA Negeri 1 Mengwi. This study used descriptive qualitative design. The subject of this study were students in IBB $11^{\text {th }}$ and the journalistic teacher in SMA Negeri 1 Mengwi. The object of this study was the implementation of writing activity in journalistic. Data 
were collected by using interview, observation, questionnaire and documentation. Data were analyzed by using descriptive qualitative technique. The result showed (1) the planning for journalistic writing was organized in the form of working agenda. The working agenda was designed into two kinds, such as working agenda for odd semester and working agenda for even semester. The component within working agenda were: purpose, target, explanation, character value and indicator of character. (2) The implementation of writing activity for journalistic were: writing news, editorial writing, writing opinion, writing specific report, writing book reviews and literature. The teacher used explaining, question and answer, discussion, practice and news as the media to make students easy to write. In addition, the teacher made the students to be sensitive with the current issues. The students were able to create journalistic writing and those writing were revised in the end of writing activities. (3) The problem faced by the students during writing were general problem and specific problem. Furthermore, the teacher also faced the problem during writing such as lack of knowledge in journalistic writing.

Keyword: extra-curricular, journalistic, writing

\section{PENDAHULUAN}

Kegiatan sekolah seperti ekstrakurikuler sangat memberikan peluang untuk siswa belajar di luar jam pelajaran. Mengingat terbatasnya jam pelajaran yang disajikan sekolah untuk program intrakurikuler, kegiatan ekstrakurikuler banyak membantu peserta didik terutama untuk mengembangkan bakat dan minat siswa. Dalam Permendikbud no 18 A 2013, ekstrakurikuler adalah kegiatan pendidikan yang dilakukan oleh peserta didik di luar jam belajar kurikulum standar sebagai perluasan dari kegiatan kurikulum dan dilakukan di bawah bimbingan sekolah dengan tujuan untuk mengembangkan kepribadian, bakat, minat, dan kemampuan peserta didik yang lebih luas atau di luar minat yang dikembangkan oleh kurikulum. Kegiatan ekstrakurikuler juga dapat dijadikam sebagai wadah untuk menyalurkan minat dan bakat siswa.

Selain itu, kegiatan ekstrakurikuler juga diharapkan mampu memberikan keterampilan yang dapat digunakan setelah selesai mengikuti kegiatan tersebut. Melalui kegiatan ekstrakurikuler siswa dapat menyalurkan minat dan bakat yang telah dimiliki. Selain dapat dijadikan wadah untuk menyalurkan minat dan bakat siswa, kegiatan ekstrakurikuler diharapkan juga mampu memberikan skill (kecakapan hidup) kepada siswa setelah selesai mengikuti kegiatan tersebut. Kegiatan ini biasanya dapat dilakukan secara berkala atau hanya dalam waktu-waktu tertentu. Melalui kegiatan ini siswa diharapkan mampu aktif dalam berbagai kegiatan baik intrakurikuler maupun ekstrakurikuler.

Dari sekian banyak kegiatan ekstrakurikuler yang ada di sekolah, kegiatan ekstrakurikuler jurnalistik salah satu kegiatan yang dapat dijadikan wadah untuk menyalurkan minat dan bakat siswa. Dalam Permendikbud no 18 A 2013, kegiatan jurnalistik masuk ke dalam jenis kegiatan latihan atau olah bakat. Melalui kegiatan jurnalistik, bakat siswa terhadap kegiatan menulis tentu dapat diasah dengan baik. Kegiatan jurnalistik sebenarnya telah lama dikenal di dunia ini. Jurnalistik selalu hadir di tengah-tengah masyarakat, sejalan dengan kegiatan pergaulan hidupnya yang dinamis, terutama masyarakat modern seperti sekarang ini. Konsep jurnalistik menurut Wikipedia dulu dikenal dengan istilah publisistik. Dua istilah ini tadinya biasa dipertukarkan, hanya berbeda asalnya. Beberapa kampus di Indonesia sempat menggunakannya karena berkiblat 
kepada Eropa. Seiring waktu, istilah jurnalistik muncul dari Amerika Serikat dan menggantikan publisistik dengan jurnalistik. Jurnalistik menurut KBBI yaitu hal yang menyangkut kewartawanan dan persuratkabaran. Suhandang (2004:23) menyatakan bahwa perkembangan jurnalistik dimulai dari perkembangan publisistik sebagai pengetahuan kemasyarakatan dalam bidang pernyataan antarmanusia. Jurnalistik sangat berperan bagi sekolah, peran yang diberikan yaitu ajang pengembangan bakat siswa, sebagai media untuk meningkatkan minat baca siswa, dan sebagai media penyebaran informasi.

Kegiatan utama dalam jurnalistik adalah menulis. Keterampilan seorang jurnalis atau wartawan yaitu menulis. Mencari informasi, mengolah informasi tersebut kemudian mempublikasikan hasil informasi yang ditulis. Melalui kegiatan jurnalistik siswa akan diajarkan menghasilkan tulisan-tulisan jurnalistik seperti berita, opini, tajuk rencana, laporan khusus, laporan utama, resensi, dan penulisan sastra. Selain itu, siswa juga dapat merasakan bagaimana pekerjaan wartawan melalui kegiatan ekstrakurikuler jurnalistik. Melalui kegiatan jurnalistik ini, siswa akan diajak berekspresi melalui berbagai macam tulisan.

Namun, kenyataan yang ada dilapangan bahwa keterampilan menulis hingga saat ini masih dipandang sebagai keterampilan yang paling sulit dibandingkan dengan keterampilan berbahasa lainnya. Hal ini terlihat dari sedikitnya jumlah siswa yang mengikuti ekstrakurikuler jurnalistik. Bahkan, hampir tidak ada yang mengikuti ekstrakurikuler jurnalistik dikarenakan menulis merupakan kegiatan yang mendominasi dalam ekstrakurikuler ini. Siswa lebih memilih mengikuti ekstrakurikuler yang lain seperti, ekstrakurikuler pada cabang olahraga, ekstrakurikuler tari dan tabuh, musik, dan lainnya. Pentingnya kegiatan jurnalistik membuat kegiatan jurnalistik hampir ada di setiap sekolah. Seperti di SMA Negeri 1 Mengwi. Ekstrakurikuler jurnalistik selalu ada dalam kegiatan ekstrakurikuler. Kegiatan ini telah lama berada dalam deretan ekstrakurikuler yang ada di sekolah tersebut. Meskipun kegiatan ini sangat sedikit di minati oleh siswa, namun pihak sekolah tetap mengadakan ekstrakurikuler jurnalistik. Peserta ekstrakurikuler jurnalistik ini siswa kelas XI jurusan bahasa. Jurusan bahasa dirasa sangat perlu mendapatkan pengalaman lebih mengenai kegiatan tulismenulis di luar jam pelajaran bahasa Indonesia.

Kehadiran guru pembina dalam kegiatan ekstrakurikuler sangat penting. Hal ini dikarenakan pembinalah yang akan mengarahkan, dan memfasilitasi siswa pada saat mengikuti ekstrakurikuler. Pada kegiatan ekstrakurikuler yang ada di sekolah, haruslah memiliki seorang guru pembina. Tanpa adanya guru pembina, kegiatan tersebut tidak dapat berjalan karena tidak ada yang mengarahkan. Guru pembina pada ekstrakurikuler bisa dari pihak sekolah maupun di luar sekolah. Namun, yang ada di lapangan bahwa pembina ekstrakurikuler berasal dari sekolah itu sendiri yakni guru yang diberikan wewenang oleh kepala sekolah. Suryosubroto (2002:289) mengemukakan bahwa guru pembina ekstrakurikuler adalah guru atau oetugas khusus yang ditunjuk oleh kepala sekolah untuk membina kegiatan ekstrakurikuler yang berfungsi sebagai pemberi pengarahan dan pembinaan kepada siswa agar ekstrakurikuler tersebut berjalan dengan tidak mengganggu ataupun merugikan aktivitas akademis. Tugas seorang guru pembina ekstrakurikuler adalah membina siswa dalam upaya mengembangkan potensi yang dimiliki siswa. 
Dalam pelaksanaan kegiatan

menulis pada ekstrakurikuler, seorang pembina menggunakan metode khusus. Adanya metode dalam pelaksanaan kegiatan menulis tentu akan memudahkan siswa serta pembina. Tidak hanya penggunaan metode, penggunaan media dalam pelatihan menulis akan membantu pembina maupun siswa. Seorang pembina juga memerlukan referensi terkait pelaksanaan kegiatan menulis pada ekstrakurikuler jurnalistik. Saat melakukan observasi awal, pembina ekstrakurikuler jurnalistik Riasih Riawati, S.Pd. menceritakan bahwa dirinya menggunakan beberapa metode dan referensi untuk mempermudah dalam pelatihan menulis. Dengan menggunakan metode tersebut dapat mempermudah siswa dan mampu bagi siswa untuk menghasilkan tulisan jurnalistik.

Pemilihan SMA Negeri 1 Mengwi sebagai tempat penelitian karena sekolah ini merupakan salah satu SMA yang aktif melaksanakan kegiatan ekstrakurikuler jurnalistik. Dilihat dari segi ekstrakurikuler, ekstrakurikuler jurnalistik memiliki kedudukan yang berbeda dibandingkan dengan ekstrakurikuler lainnya. Untuk mempertahankan ekstrakurikuler jurnalistik pihak sekolah mengambil keputusan untuk mewajibkan siswa yang memilih jurusan bahasa wajib mengikuti ekstrakurikuler jurnalistik. Pihak sekolah menganggap keberadaan ekstrakurikuler di sekolah sangat penting untuk dijadikan wadah kreativitas siswa dan sebagai wadah untuk bertukar informasi. Melalui kegiatan ekstrakurikuler jurnalistik, diharapkan siswa dapat berekspresi melalui tulisan. Selain itu, pemilihan jurusan XI IBB dalam mengikuti ekstrakurikuler jurnalistik karena siswa jurusan bahasa sangat dekat dengan kegiatan menulis. Jurnalistik dan menulis memiliki hubungan yang sangat erat. Kegiatan menulis sangat penting didapatkan oleh siswa karena dalam pembelajaran bahasa Indonesia, kegiatan menulis memerlukan waktu yang tidak sedikit. Sehingga, dalam pembelajaran bahasa Indonesia khususnya menulis kurang merinci. Maka dari itu, siswa jurusan bahasa harus memiliki pengalaman lebih terkait kegiatan menulis.

Meskipun siswa diwajibkan untuk mengikuti ekstrakurikuler jurnalistik, siswa mampu menghasilkan tulisan jurnalistik. Hal tersebut berkaitan dengan adanya metode khusus yang digunakan oleh pembina. Saat melakukan observasi awal, pembina jurnalistik menceritakan tim jurnalistik aktif mengikuti perlombaan. Baik tim maupun siswa pribadi, selalu aktif dalam mengikuti perlombaan menulis. Tim jurnalistik berhasil menyabet juara I di acara d'Jafu 2017 tingkat provinsi. Bermula dari sinilah, kini ekstrakurikuler jurnalistik SMANGI mulai aktif dan bangkit kembali. Berdasarkan halhal tersebut, dapat diasumsikan bahwa kegiatan menulis pada ekstrakurikuler jurnalistik berjalan dengan baik. Jadi, dalam penelitian ini SMA Negeri 1 Mengwi ditetapkan sebagai subjek penelitian. Maka penelitian ini diberi judul "Kegiatan Menulis pada Ekstrakurikuler Jurnalistik di SMA Negeri 1 Mengwi".

Terdapat beberapa penelitian sejenis mengenai kegiatan menulis yang dilakukan oleh peneliti lain. Penelitian pertama oleh Endriana (2015) dengan judul "Strategi Guru dalam Pembelajaran Menulis Berita pada Ekstrakurikuler Jurnalistik di SMA Negeri 1 Kintamani”. Penelitian kedua oleh Dwijayanti (2015) dengan judul "Pembelajaran Menulis Opini Berbasis Media Video Berita di Televisi pada Siswa Kelas X.2 SMA Negeri 1 Sawan". Penelitian sejenis ketiga yang dilakukan oleh Nurlailatul (2016) yang berjudul "Pembelajaran Menulis Teks Prosedur Berdasarkan Hasil Wawancara di kelas VIII A1 SMP Negeri 1 Singaraja". 
Ketiga jenis penelitian tersebut memiliki kesamaan yaitu mengenai kegiatan menulis dan ekstrakurikuler jurnalistik. Namun, dibalik adanya persamaan dalam penelitian tersebut penelitian ini berfokus pada kegiatan menulis yang dilaksanakan pada ekstrakurikuler jurnalistik. Hal inilah yang menarik perhatian peneliti untuk mengkaji lebih lanjut tentang kegiatan menulis yang didapatkan siswa pada saat mengikuti ekstrakurikuler jurnalistik. Berdasarkan hal tersebut, penelitian dengan judul "Kegiatan Menulis pada Ekstrakurikuler Jurnalistik Siswa di SMA Negeri 1 Mengwi" menarik dan penting dilakukan guna melengkapi penelitianpenelitian lain.

Berdasarkan hal tersebut, penelitian ini bertujuan untuk mengkaji perencanaan kegiatan menulis, pelaksanaan kegiatan menulis dan (3) mengkaji hambatan-hambatan yang dihadapi siswa dalam kegiatan menulis pada Ekstrakurikuler Jurnalistik di SMA Negeri 1 Mengwi.

\section{METODE PENELITIAN}

Penelitian ini menggunakan pendekatan kualitatif dengan jenis penelitian deskriptif kualitatif. Pendekatan deskriptif kualitatif digunakan untuk menganalisis dan mendeskripsikan perencanaan kegiatan menulis, pelaksanaan kegiatan menulis, serta hambatan yang dihadapi siswa dalam kegiatan menulis pada ekstrakurikuler jurnalistik di SMA Negeri 1 Mengwi.

Dalam penelitian ini, subjek yang diteliti adalah siswa kelas $\mathrm{XI}$ jurusan bahasa dan pembina ekstrakurikuler jurnalistik di SMA Negeri 1 Mengwi.

Objek dalam penelitian ini adalah kegiatan menulis pada ekstrakurikuler jurnalistik. Penelitian yang akan dilakukan peneliti bertempat di SMA Negeri 1 Mengwi. SMA Negeri 1 Mengwi merupakan salah satu sekolah negeri yang berada di Kabupaten Badung. Lokasi sekolah ini berada di Jalan Gunung Agung No.3 Mengwi, Desa Mengwi, Kecamatan Mengwi, Kota Mangupura, Kabupaten Badung. Peneliti memilih lokasi penelitian di sekolah tersebut karena saat melakukan observasi awal peneliti menemukan permasalahan yang unik pada kegiatan ekstrakurikuler jurnalistik. Sehingga sangat tertarik peneliti untuk teliti lebih lanjut.

Data mengenai kegiatan menulis pada ekstrakurikuler jurnalistik menggunakan metode wawancara, observasi, kuisioner, dan dokumentasi. Metode wawancara digunakan untuk memperoleh informasi atau data yeng berkaitan dengan perencanaan kegiatan menulis serta hambatan yang dihadapi siswa dalam menulis. Metode observasi digunakan untuk mengamati dan memperoleh data mengenai kegiatan menulis. Metode kuisioner terbuka digunakan untuk memeroleh jawaban siswa mengenai hambatan yang dihadapi pada kegiatan menulis. Metode dokumentasi digunakan untuk mengabadikan pelaksanaan kegiatan menulis.

Setelah melakukan pengumpulan data, langkah selanjutnya yang akan dilakukan adalah analisis data. Teknik analisis data deskriptif kualitatif data dibagi menjadi reduksi data, klasifikasi data, penyajian data, dan penarikan simpulan/verifikasi.

\section{HASIL DAN PEMBAHASAN}

Perencanaan kegiatan menulis pada ekstrakurikuler jurnalistik di SMA Negeri 1 Mengwi disusun oleh pembina dalam bentuk program kerja. Program kerja dirancang menjadi dua, yaitu program kerja semester ganjil dan program kerja semester genap. Kedua program tersebut dijadikan sebagai patokan untuk melaksanakan kegiatan pada ekstrakurikuler jurnalistik. 
Harjanto (2005:2) menyatakan, "Perencanaan berkaitan dengan penentuan apa yang akan dilakukan. Perencanaan tersebut mendahului pelaksanaan, mengingat perencanaan merupakan suatu proses untuk menentukan ke mana harus pergi". Sesuai dengan pernyataan tersebut pembina merancang program kerja sebelum akan melaksanakaan kegiatan menulis pada ekstrakurikuler jurnalistik.

Dalam program kerja yang disusun oleh pembina ada beberapa komponen yang akan menjadi patokan untuk melaksanakan kegiatan menulis pada ekstrakurikuler jurnalistik. Komponen tersebut meliputi, tujuan, sasaran, indikator karakter, nilai karakter dan uraian kegiatan. Uraian kegiatan dalam program kerja yang disusun oleh pembina dapat dibedakan menjadi dua yaitu kegiatan semester ganjil dan semester genap. Pada uraian kegiatan semester ganjil dimuat mengenai teori-teori yang akan diperoleh siswa dalam mengikuti ekstrakurikuler jurnalistik. Teori-teori tersebut di rasa sangat penting diperoleh siswa dalam mengikuti ekstrakurikuler mengingat pada semester ganjil kelas XI merupakan awal siswa mendapatkan ekstrakurikuler jurnalistik.

Menurut Suhandang, (2004:102) dalam konteks jurnalistik pemberitahuan pun dikenal sebagai produk jurnalistik yang berupa (1) news (berita), 2 views (pandangan, komentar, ulasan), dan (3) advertisement (iklan/perkenalan yang bersifat propaganda). Ketiga produk jurnalistik tersebut selalu ditemukan dalam majalah, suratkabar, siaran radio, dan siaran televisi.

Sejalan dengan pendapat yang dikemukan oleh Suhandang, pembina jurnalistik menyusun teori yang akan diperoleh dalam pelaksanaan ekstrakurikuler jurnalistik pada semester ganjil yaitu teori tajuk rencana, teori sastra, teori berita, teori penulisan laporan utama dan laporan khusus, serta teori penulisan opini.

Berbeda halnya dengan kegiatan semester ganjil, pada kegiatan semester genap lebih menonjolkan pelatihan menulis jurnalistik. Selain pelatihan menulis, dalam kegiatan ini juga menonjolkan cara kerja tim jurnalistik. Siswa akan mempraktekkan langsung teori yang telah didapatkan sebelumnya. Kegiatan semester genap ini siswa akan berfokus untuk menghasilkan tulisan-tulisan jurnalistik.

Setelah mendapatkan teori pada semester ganjil, siswa akan mampu menghasilkan tulisan pada semester genap. Tidak hanya menulis, siswa juga langsung terjun ke lapangan untuk mencari bahanbahan yang akan dijadikan sebuah tulisan. Siswa diajarkan langsung bagaimana cara meliput berita, menyusun pertanyaan untuk wawancara, mendokumentasikan peristiwaperistiwa sekitar lingkungan sekolah dan lain-lain. Sesuai dengan pernyataan yang dikemukakan oleh Suhandang (2004:100) cara kerja seorang wartawan diawali dengan kegiatan mencari dan mengumpulkan fakta (untuk bahan berita), kemudian mengolahnya, dan selanjutnya memberitakan atau menyiarkannya melalui media massa. Program kerja yang disusun oleh pembina selalu di perbaharui setiap tahun mengingat program sekolah dan osis selalu berbeda-beda. Selain itu, pembina juga menyesuaikan dengan kondisi yang ada di lapangan.

Pelaksanaan kegiatan menulis ekstrakurikuler jurnalistik pada semester ganjil lebih ditekankan mengenai teori penulisan jurnalistik. Sedangkan pada semester genap seecara garis besar, kegiatan menulis pada semester genap tahun ajaran 2017-2018 lebih ditekankan mengenai praktek menulis jurnalistik. Pertemuan pertama berlangsung pada hari senin, 16 April 2018 pukul 14.00 sampai 15.00 wita bertempat di kelas XI IBB. Pada 
pertemuan ini pembina memberikan praktek menulis berita. Pembina menggunakan metode ceramah untuk mengingatkan siswa pada materi berita yang telah diperoleh semester ganjil. Menurut Sagala (2010:201) metode ceramah adalah sebuah bentuk interaksi melalui penerangan dan penuturan lisan dari guru kepada siswa. Dalam proses menulis, pembina menggunakan metode diskusi. Pembina memberikan contoh berita yang ada pada koran. Siswa dibebaskan memilih berita yang hendak di analisis. Siswa diperintahkan untuk mencari struktur berita, unsur berita, dan syarat penulisan berita. Kemudian, siswa diperintah untuk membuat berita dengan cara mencontoh apa yang telah dianalisis. Hasil dari tulisan siswa pada saat pertemuan itu langsung di koreksi bersama-sama. Siswa mampu menulis berita yang berjudul "Pentaque SMANGI sabet 4 Medali dalam Porjar Badung 2018".

Pertemuan kedua berlangsung pada tanggal 18 April 2018. Pada pertemuan ini siswa berlatih menulis Opini. Dalam proses penulisan opini, pembina mengaitkan isuisu yang sedang terjadi di lingkungan sekolah. Mengingat bahwa opini adalah tulisan lepas yang berisi opini seseorang yang mengupas tuntas suatu masalah tertentu yang sifatnya actual dan atau kontroversi dengan tujuan untuk memberitahu (informatif) memengaruhi, dan menyakinkan atau juga bisa menghibur pembacanya bersifat recreative (Kuncoro, 2009:32). Hasil tulisan siswa pada praktek penulisan opini yaitu hanya satu siswa yang mampu menghasilkan opini. Siswa tersebut diminta untuk membacakan hasil tulisannya di depan teman-temannya. Hasil tulisan siswa tersebut berjudul "Pentingnya Pengolahan Sampah di Lingkungan Sekolah".

Pertemuan ketiga yaitu pada tanggal 20 April 2018 kegiatan menulis pada ekstrakurikuler jurnalistik yaitu praktek menulis tajuk rencana. Pada praktek penulisan tajuk rencana, pembina menggunakan metode diskusi. Dalam penulisan tajuk, pembina menyarankan siswa agar langsung mengungkapkan apa yang ingin disampaikan terhadap isu yang diangkat. Sejalan dengan Syamsul (2005:90) menyatakan tulisan kolom atau tajuk rencana tidak mempunyai struktur tertentu, misalnya ada bagian pendahuluan atau lead, isi atau tubuh tulisan, dan penutup. Hasil tulisan siswa yaitu berupa tulisan tajuk rencana yang berjudul "Kearifan Lokal Bentengi Gaya Kekinian" dan Efek Renovasi Gedung Sekolah Terhadap Proses Belajar Siswa.

Pertemuan keempat pada pelaksanaan kegiatan menulis berlangsung pada tanggal 22 April 2018 yaitu praktek menulis laporan utama dan laporan khusus. Pembina menggunakan metode ceramah laporan utama dan khusus sebelum lanjut untuk praktek menulis. Pembina menggunakan laporan yang ada pada koran sebagai contoh untuk memudahkan siswa dalam menulis laporan. Siswa dapat menyelesaikan tugas menulis tersebut dengan tepat waktu. Hasil tulisan siswa mengenai laporan utama berjudul "Cak Kolosal Berawa Beach Art Festival yang Melibatkan 5555 Orang Pecahkan Rekor Muri Dunia" dan laporan khusus dengan judul "Vasudeva Devaki Berhasil Bawa Pulang Piala Gubernur Taksaka IX".

Pertemuan kelima pada tanggal 25 April 2018 berlangsung pada pukul 14.30 sampai dengan 15.30 wita. Pada pertemuan ini siswa akan menulis rensensi. Pembina membebaskan siswa untuk merensensi apapun yang tengah marak diperbincangkan. Siswa harus mampu berpendapat mengenai hasil karya milik seseorang baik menyampaikan kelebihan maupun kekurangan dari karya tersebut. Baik itu berupa rensensi buku, musik, ataupun film. Proses kegiatan menulis 
resensi ini, pembina menggunakan metode diskusi bersama kelompok. Pembina juga menjelaskan mengenai struktur penulisan resensi yaitu, bagian pendahuluan, bagian isi, dan penutup. Hasil dari tulisan siswa yaitu resensi buku yang berjudul "Tottochan", resensi film yang berjudul "Unfriended; Dark Web" dan resensi musik berjudul "Fake Optics".

Pertemuan keenam berlangsung pada tanggal 26 April 2018 berlangsung pukul 14.00 sampai 15.00 wita. Materi sastra yang didapatkan siswa dalam ekstrakurikuler jurnalistik hanya mencakup cerpen dan puisi. Pada kegiatan ini, pembina menggunakan teknik kreatif. Siswa dibebaskan untuk berpikir secara kreatif dalam menghasilkan tulisan. Sesuai dengan pendapat Widijanto (2007:69) menyatakan bahwa kegiatan menulis puisi pada dasarnya adalah kegiatan yang bersifat produktif kreatif yang melalui sebuah proses dinamakan proses kreatif. Proses kreatif hanya mengalir dalam suasana yang kreatif yang memungkinkan lahirnya karya-karya yang secara bahasa indah dari segi pemikiran cukup dalam. Pembina hanya mendampingi siswa untuk menghasilkan puisi maupun cerpen. Hasil tulisan pada kegiatan tersebut menghasilkan tulisan puisi dan cerpen. Puisi yang berjudul "DUA SISI KACA" dan cerpen yang berjudul "Ilmu Hitam di Dekat Pusara".

Hambatan yang dihadapi siswa dalam kegiatan menulis ditinjau dari segi teori dapat dibedakan menjadi dua yaitu hambatan secara umum dan khusus. Hambatan umum yaitu hambatan yang dialami oleh semua penulis pemula. Hambatan tersebut wajar terjadi dalam diri seorang penulis. (1) Hambatan menentukan topik yang akan ditulis. "Hambatan yang saya alami dalam menulis yaitu saat mencari topik yang akan ditulis. Karena dalam menulis topik kita harus menguasai dulu materinya. Jika tidak materi dan topik yang kita bahas tidak akan sesuai" (Sudarminin Putri). Siswa merasa kesulitan saat menentukan topik karena takut tidak bisa mengembangkan topik tersebut menjadi sebuah tulisan yang utuh. Sejalan dengan Zainurrahman (2013:206) yang mengatakan bahwa "hambatan memilih topik merupakan masalah yang umum dijumpai dan dialami oleh setiap orang yang akan menulis. (2) Hambatan menyusun kalimat efektif, "Hambatan yang saya hadapi ketika menulis yaitu Hambatan yang saya hadapi ketika menulis yaitu pada saat kalimat yang saya buat rancu dan kurang di mengerti. Saya susah membuat kalimat yang efektif dan dimengerti pembaca". (Gandhika Dharma)

Hambatan ini merupakan salah satu hambatan yang umum di jumpai ketika menulis baik itu menulis karya ilmiah maupun menulis karya sastra. Hal ini sejalan dengan pendapat yang di kemukan oleh Maslakhah (dalam Wiedarti, 2005:22) yang menyatakan bahwa "umumnya tidak semua orang dapat menyusun kalimat dengan ragam baku (tidak dapat menyusun kalimat efektif) dengan baik. Akibatnya, ditemukan cukup banyak kalimat yang tidak baku dalam tulisannya". (3) Hambatan dalam menentukan judul, "Saya sulit untuk menentukan judul pada tulisan. Tulisan saya sudah selesai, malah saya kebingungan mencari judul apa yang tepat dan cocok sesuai dengan isi tulisan". (Sayu Rahma). Hambatan ini salah satu hambatan umum yang dihadapi siswa. Beberapa siswa yang telah menjawab pertanyaan pada kuisioner menyatakan bahwa dirinya sangat sulit menentukan judul. Ketika di wawancara secara langsung, mereka membenarkan bahwa menentukan judul dalam sebuah tulisan di rasa sangat susah. (4) Hambatan pemilihan kata, "Hambatan yang saya hadapi ketika menulis yaitu ketika memilih kata yang cocok untuk saya gunakan dalam tulisan saya. Saya kurang 
pengalaman menulis, sehingga susah dalam menentukan kata agar tepat dan menarik". (Eni Purwati)

Ketika menulis, siswa juga mengalami hambatan khusus. Hambatan khusus ini hambatan yang bersumber pada diri seseorang. Sesuai dengan pendapat Zainurrahman (2013:206) yang menyatakan bahwa "hambatan khusus merupakan hambatan yang dialami oleh tiap penulis secara berbeda. Hambatan ini bersumber pada dalam diri seorang penulis tersebut. Seperti halnya kehilangan mood menulis". Mood yang dimaksud adalah semangat dan keselarasan hati untuk menulis. Setiap orang tentu mengalami hambatan menulis yang berbeda-beda. Seperti halnya dengan beberapa siswa yang mengalami hambatan khusus dalam kegiatan menulis sebagai berikut. (1) Saya kalau menulis tergantung mood. Biasanya saya akan bisa dapat ide dan menulis pas lagi moodnya buruk banget. Karena ketika itu biasanya ide sama apa yang saya mau tulis bisa keluar dengan lancar. Tapi kalo moodnya bagus malah jadi hambatan menulis. (Nurzaidatun Rohmah). (2) Hambatan yang saya hadapi ketika menulis ketika sedang dalam kondisi tidak baik, seperti saat bosan, lelah, dan mengantuk. Sehingga tidak ada hasrat untuk menulis". (Tiara Putri). (3) Saya tidak terlalu tertarik untuk menulis, selain itu juga saya malas menulis. Ketika menulis saya cepat mengantuk dan cepat bosan sehingga tidak ingin menulis. Selain itu, saya tidak mempunyai niat untuk menulis ketika hendak menulis tangan saya tidak mau bergerak". (Eni Purwati) (4). Ketika menulis saya kurang percaya diri dengan apa yang saya telah tulis. Ada keinginan takut untuk memperlihatkan kepada orang lain" (Elda)

Selain hambatan yang dihadapi siswa, pembina juga mengalami hambatan ketika menulis pada ekstrakurikuler jurnalistik. Dalam menentukan metode untuk melatih siswa dalam kegiatan menulis. Pembina tidak dapat menggunakan metode ataupun teknik yang tepat dalam kegiatan menulis. Hal tersebut dikarenakan keterbatasan pengetahuan pembina terkait kegiatan menulis jurnalistik. Selain itu, bahan ajar yang digunakan pembina sangat terbatas. Pembina hanya menggunakan buku-buku yang didapatkan pada saat workshop dan mencari bahan ajar di internet. Hambatan juga bersumber dari sekolah itu sendiri. Adanya banyak kegiatan sekolah serta libur untuk persiapan ujian mengakibatkan kegiatan ekstrakurikuler tidak berlangsung sesuai dengan jadwal yang telah direncanakan. Sehingga dampak yang diakibatkan kepada kegiatan menulis jurnalistik yaitu tidak dapat berjalan sesuai dengan yang direncanakan. Padahal kegiatan menulis memerlukan waktu yang tidak sedikit. Berhubung banyak libur dan kegiatan lainnya, sehingga kegiatan menulis pada jurnalistik di akhir semester dipercepat guna menyelesaikan praktek yang belum terselesaikan. Hal tersebut tentu berpengaruh terhadap kondisi belajar siswa. Siswa merasa kelelahan ketika mengikuti ekstrakurikuler akan menganggu konsentrasi menulis. Hambatan juga bersumber pada diri siswa itu sendiri yaitu tidak adanya motivasi dan minat untuk mengikuti kegiatan menulis. Sehingga ketika menulis, siswa merasa susah dan kurang percaya diri.

Terkait cara siswa untuk mengatasi hambatan menulis yang mereka alami secara garis besar yaitu dengan mencari refrensi di internet ataupun buku-buku di perpustakaan sekolah. Selain itu, cara lain yang dilakukan oleh siswa dengan bertanya langsung kepada pembina maupun teman yang sudah berpengalam dalam menulis. Dengan cara seperti itu, tentu akan memudahkan siswa dalam kegiatan menulis. Siswa juga mengatakan bahwa memerlukan suasana yang tenang dan 
nyaman dalam kegiatan menulis. Kondisi yang tenang dan nyaman, tentu akan meningkatkan konsentrasi siswa dalam menghasilkan tulisan. Ketika sudah mendapatkan sebuah ide/topik yang akan ditulis, dengan segera siswa mencatat halhal tersebut ke dalam bentuk draf. Kemudian hal-hal tesebut dikembangkan ke dalam sebuah tulisan.

Berdasarkan uraian di atas, kegiatan menulis pada ekstrakurikuler jurnalistik di SMA Negeri 1 Mengwi tergolong baik. Terlihat pada perencanaan kegiatan menulis, pembina menyusun program kerja yang dibagi menjadi dua hal yaitu program kerja semester ganjil dan semester genap. Pelaksanaan kegiatan menulis, telah sesuai dengan program kerja yang disusun.. Hambatan yang dihadapi siswa dalam kegiatan menulis meliputi hambatan umum dan khusus. Selain hambatan umum dan khusus, hambatan tersebut bersumber dari pembina, sekolah, dan siswa.

\section{SIMPULAN DAN SARAN}

Berdasarkan hasil dan pembahasan ada beberapa hal yang dapat disimpulkan dalam penelitian ini sebagai berikut.

Perencanaan kegiatan menulis pada ekstrakurikuler jurnalistik disusun dalam bentuk program kerja. Program kerja dirancang menjadi dua, yaitu program kerja semester ganjil dan program kerja semester genap. Komponen yang terdapat dalam program kerja tersebut meliputi tujuan, sasaran, uraian kegiatan, nilai karakter, dan indikator karakter. Dalam uraian kegiatan ada dua hal yang akan dilaksanakan yaitu kegiatan semester ganjil memperkenalkan dasar-dasar atau menjelaskan teori-teori tentang menulis pada jurnalistik dan kegiatan semester genap yaitu pelatihan atau praktek menulis.

Pelaksanaan kegiatan menulis pada ekstrakurikuler jurnalistik pada semester ganjil lebih ditekankan mengenai teori penulisan jurnalistik. Sedangkan pada semester genap secara garis besar lebih menekankan praktek menulis. Praktek menulis yang akan dilaksanakan yaitu meliputi menulis berita, opini, tajuk rencana, laporan umum, laporan khusus, resensi buku, dan menulis sastra. Pada pelaksanaan kegiatan menulis pembina menggunakan metode ceramah, tanya jawab, diskusi, dan praktek. Pada proses penulisan opini dan tajuk rencana pembina mengajak siswa untuk peka terhadap isuisu yang hangat diperbincangkan. Sedangkan dalam proses penulisan sastra, pembina menggunakan teknik berpikir kreatif dalam menghasilkan puisi dan cerpen. Pada penulisan ini, siswa dibebaskan untuk menulis sekreatif mungkin. Hasil kegiatan menulis yaitu siswa mampu menghasilkan tulisan-tulisan jurnalistik. Tulisan tersebut di koreksi ketika akhir pelatihan kegiatan menulis..

dalam kegiatan yang dihadapi siswa ekstrakurikuler yaitu meliputi hambatan umum dan hambatan khusus. Hambatan umum yaitu hambatan yang sering dijumpai ketika menulis baik itu tulisan karya ilmiah maupun karya sastra. Adapun hambatan umum yang sering dihadapi siswa meliputi hambatan menentukan topik, menyusun kalimat efektif, hambatan menentukan judul, dan menentukan kata-kata yang cocok. Berbeda halnya dengan hambatan umum, hambatan khusus bersumber pada diri seseorang. Seperti tidak mood ketika menulis, kelelahan karena jam pelajaran full, kurang percaya diri, serta sedikitnya dukungan disekitar. Pembina selalu memberikan masukan langsung maupun tidak langsung ketika siswa menghadapi hambatan ketika menulis.

Selain hambatan yang dihadapi siswa, pembina juga mengalami hambatan ketika menulis pada ekstrakurikuler jurnalistik. Dalam menentukan metode 
untuk melatih siswa dalam kegiatan menulis. Pembina tidak dapat menggunakan metode ataupun teknik yang tepat dalam kegiatan menulis. Hal tersebut dikarenakan keterbatasan pengetahuan pembina terkait kegiatan menulis jurnalistik. Selain itu, bahan ajar yang digunakan pembina sangat terbatas. Pembina hanya menggunakan buku-buku yang didapatkan pada saat workshop dan mencari bahan ajar di internet. Hambatan juga bersumber dari sekolah itu sendiri. Adanya banyak kegiatan sekolah serta libur untuk persiapan ujian mengakibatkan kegiatan ekstrakurikuler tidak berlangsung sesuai dengan jadwal yang telah direncanakan. Sehingga dampak yang diakibatkan kepada kegiatan menulis jurnalistik yaitu tidak dapat berjalan sesuai dengan yang direncanakan. Padahal kegiatan menulis memerlukan waktu yang tidak sedikit. Selain itu, hambatan juga bersumber pada diri siswa itu sendiri yaitu kurang motivasi dan minat untuk mengikuti kegiatan menulis. Untuk mengatasi hambatan-hambatan tersebut, siswa memiliki cara tersendiri yaitu seperti mencari referensi di internet, membaca buku diperpustakaan, dan diskusi dengan teman yang memiliki pengalaman menulis. Selain itu, peran guru sangat penting dalam mengatasi hambatan yang siswa hadapi.

Berdasarkan hasil penelitian dan simpulan yang telah disampaikan, saran yang dapat disampaikan dalam penelitian ini adalah sebagai berikut.

Pertama, bagi sekolah diharapkan untuk mencari praktisi yang mampu membina ekstrakurikuler jurnalistik. Dengan demikian, kegiatan jurnalistik lebih sejalan dengan pengalaman yang dimiliki oleh seorang wartawan. Akan lebih mampu memberikan pengalaman terkait kewartawanan serta menyediakan waktu lebih banyak untuk kegiatan ekstrakurikuler.

Kedua, bagi lembaga pers agar memerhatikan kegiatan jurnalistik yang ada pada sekolah-sekolah. Kegiatan jurnalistik sangat perlu diperoleh oleh kalangan siswa menengah pertama dan menengah atas karena dalam pembelajaran bahasa Indonesia siswa kurang mendapatkan pengalaman mengenai menulis. Melalui kegiatan ekstrakurikuler jurnalistik ini, siswa mendapatkan pengalaman mengenai kegiatan menulis. Sehingga dibutuhkan kesediaannya untuk membagi ilmu secara langsung dalam kegiatan esktrakurikuler jurnalistik. Ekstrakurikuler jurnalistik perlu dibina langsung oleh wartawan, sehingga siswa dapat langsung merasakan pekerjaan seorang wartawan selain mendapatkan pengalaman menulis.

\section{DAFTAR PUSTAKA}

Dwijayanti, Made. 2015. "Pembelajaran Menulis Opini Berbasis Media Video Berita di Televisi pada Siswa Kelas X.2 SMA Negeri 1 Sawan". Skripsi (tidak diterbitkan). Singaraja: Universitas Pendidikan Ganesha.

Endriana, Wayan. 2015. "Strategi Guru dalam Pembelajaran Menulis Berita pada Ekstrakurikuler Jurnalistik di SMA Negeri 1 Kintamani". Skripsi (tidak diterbitkan). Singaraja: Universitas Pendidikan Ganesha.

Harjanto, 2005. Perencanaan Pengajaran. Jakarta: Rineka Cipta.

Kuncoro, Mudrajad. 2009. Mahir Menulis Kiat jitu Menulis Artikel, Opini, Kolom dan Resensi Buku. Bandung: PT. Remaja Rosdakarya.

Nurlailatul, Siti. 2016. "Pembelajaran Menulis Teks Prosedur Berdasarkan Hasil Wawancara di kelas VIII A1 SMP Negeri 1 Singaraja". Skripsi (tidak diterbitkan). Singaraja: Universitas Pendidikan Ganesha. 
Permendikbud. 2013. "Peraturan Menteri Pendidikan dan Kebudayaan Repbulik Indonesia Nomor 81a Tahun 2013 tentang Implementasi Kurikulum Pedoman Kegiatan Ekstrakurikuler Lamp. III tersedia pada halaman https://www.scribd.com/doc/20340511 6/Lampiran-III-Pedoman-KegiatanEkstrakurikuler (diakses tanggal 28 februari 2018)

Sagala, Syaiful. 2010. Konsep dan Makna Pembelajaran. Bandung: Alfabeta.

Suhandang, Kustadi. 2004. Pengantar Jurnalistik. Bandung: Penerbit Nuansa.
Suryosubroto. 2002. Proses Belajar Mengajar di Sekolah. Jakarta: PT. Rineka.

Syamsul, Asep. 2005. Jurnalistik Praktis Untuk Pemula. Bandung: PT Remaja Rosdakarya.

Widijanto, Tjahjono. 2007. Pengajaran Sastra yang Menyenangkan. Bandung: PT Pribumi Mekar.

Zainurrahman. 2013. Menulis: Dari Teori Hingga Praktik (Penawaran Racun lagiarisme). Bandung: Alfabeta. 


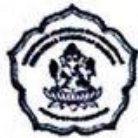

KEMENTERIAN RISET, TEKNOLOGI DAN PENDIDIKAN TINGGI UNIVERSITAS PENDIDIKAN GANESHA FAKULTAS BAHASA DAN SENI TIM E-JOURNAL PENDIDIKAN BAHASA DAN SASTRA INDONESIA

\section{SURAT SIAP PUBLIKASI ARTIKEL}

No : 91/EJPS/SPNII/2018

Kepada Yth:

Tim e-Journal Pendidikan Bahasa dan Sastra Indonesia

Dengan ini menyatakan bahwa artikel di bawah ini:

Judul

: KEGIATAN MENULIS PADA EKSTRAKURIKULER JURNALISTIK

DI SMA NEGERI 1 MENGWI

Penulis I : NI PUTU ANA YUSPIDAYANTI

Pembimbing I : DR. I WAYAN ARTIKA,S.PD,M.HUM

Pembimbing II : DRS.I GEDE NURJAYA,M.PD

Program Studi : PENDIDIKAN BAHASA DAN SASTRA INDONESIA

Siap untuk dipublikasikan pada Pendidikan Bahasa dan Sastra Indonesia

Demikian surat ini kami sampaikan, atas perhatian dan kerjasamanya diucapkan terima kasih.

Pembimbing II

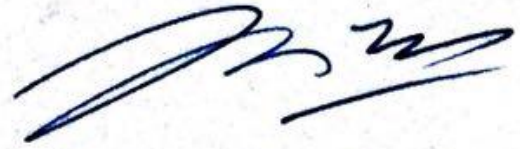

Drs.I Gede Nurjaya,M.Pd NIP. 196503201990031002
Singaraja,

Pembimbing I

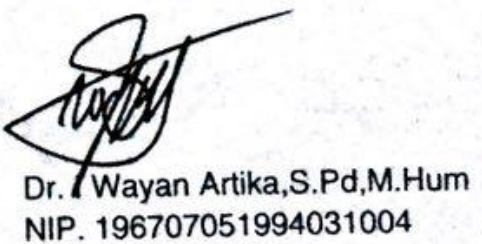

